\title{
Evaluation of a prototype for a reference platelet counter
}

\author{
S M Lewis, R M Rowan, F Kubota
}

\begin{abstract}
A semiautomated single channel aperture-impedance particle counter was developed as a prototype for a reference platelet count for assigning values to reference preparations used in automated blood cell counts. The instrument is equipped with sheath flow and an aperture orifice of $50 \mu \mathrm{m}$ in diameter and $60 \mu \mathrm{m}$ in length to eliminate non-axial flow and minimise coincidence errors. Use of fixed volume and red blood cell:platelet ratios obviate dilution errors.

The counter was assessed in accordance with the International Committee for Standardization in Haematology protocol for evaluation of automated blood cell counters. The counter provided a high level of linearity and precision, accurate coincidence correction, controlled volume, stability and negligible carryover.
\end{abstract}

The accurate counting of platelets is assuming increasing importance in the care of patients, particularly those with thrombocytopenia. Examination of the data published by various national external quality assessment bodies, particularly NEQAS in the United Kingdom, Etaonorme in France, and the College of American Pathologists, indicates a continuing trend toward whole blood counting methods.

Modern blood cell counters are capable of a high degree of precision, but there is often considerable variation among instruments. Harmonisation between different counting systems requires calibration by means of reference preparations with accurately assigned values. ${ }^{1}$ Counters which can provide a sufficiently high level of accuracy and reproducibility are needed to assign values to reference preparations for use in calibration.

A semiautomated single channel apertureimpedance counter with a transducer to detect the passage of cells has been developed by Toa Medical Electronics Ltd for this purpose, and its red cell counting capacity has been evaluated. ${ }^{2}$ This instrument seemed to be an eminently suitable reference counter when used in conjunction with a procedure for coincidence correction. ${ }^{3}$

A further modification, based on the aperture-impedance principle, was designed to provide an instrument (Sysmex Model SSF) for platelet counting. This has an orifice diameter: length of $50 \times 60 \mu \mathrm{m}$ with a sheath flow which eliminates non-axial passage of cells, minimises coincidence error, and prevents recirculation at the orifice. Flow rate is controlled by a syringe unit which injects a fixed volume of sample $(11.86 \mu \mathrm{l})$ into the sheath flow in 14 seconds. A pulse height analyser is linked to the counter to check and set moving thresholds. A curve is fitted to the data and particles which appear under the fitted curve are distinguished from noise level and microcytic red cells, respectively.

The recorded data include platelet count, red cell count, mean platelet volume (MPV) and platelet size distribution.

Data received from the counting system pass to a microcomputer for correction of coincidence error for both red blood cells and platelets by either logarithmic or linear extrapolation as appropriate. The programme for this takes account of the problem which occurs when more than one cell type is being counted by the same detector; it involves calculating the probabilities of coincidence in red blood cell and platelet cross counting. ${ }^{4}$ Comparison of the red blood cell with the red cells counted on the reference counter ${ }^{2}$ confirms that the displaced volume has been constant. It also provides comparison of the direct platelet count with the red blood cell: platelet ratio procedure originally proposed as a reference method by ICSH. ${ }^{1}$

The counter was evaluated in London (Laboratory A) and Glasgow (Laboratory B) in accordance with the ICSH protocols. ${ }^{5}$

\section{Methods}

Whole blood, in $\mathrm{K}_{2}$-EDTA anticoagulant, was used for all measurements. The blood was diluted 1 in 500 in Cell pack (Toa Medical Electronics Ltd). The diluted samples were contained in Toa DB-1 pots which were shown to prevent surface adhesion of cells and not to influence their size. Counts were delayed until all visible bubbles due to mixing had disappeared. Except for the study of drift, the counts were made within the stability period for the diluted samples.

For all dilutions, the pipettes used were officially tested class A glassware, clean and free from chipping, as defined by ICSH. ${ }^{1}$

\section{Results}

EFFECT OF DILUTION

As the instrument is a ratio counter evaluating both red cells and platelets, and a complex coincidence correction algorithm is incor- 
porated, the effect of dilution over anticipated working ranges for both red cells and platelets needs to be assessed.

Replicate tests (three at each dilution) were performed to give results at 10 evenly spaced concentrations, between $10 \%$ and $100 \%$ volumes by dilutions of platelets in autologous platelet poor plasma (A). The accuracy of pipetting was checked by estimating the haemoglobin concentration at each dilution by the haemiglobincyanide method using spectrophotometers calibrated with the ICSH Reference Standard. ${ }^{6}$

Table 1 Effects of dilution on linearity

\begin{tabular}{lccl}
\hline Experiment & Slope & Intercept & $\begin{array}{l}\text { Correlation } \\
\text { coefficient }(R)\end{array}$ \\
\hline $\begin{array}{c}\text { A Low platelets in } \\
\text { platelet poor plasma }\end{array}$ & 0.734 & 2.612 & 0.9955 \\
$\begin{array}{c}\text { A High platelets in } \\
\text { platelet poor plasma }\end{array}$ & 0.956 & -0.079 & 0.9977 \\
$\begin{array}{c}\text { B1 High platelets low } \\
\text { red blood cells }\end{array}$ & 0.990 & 0.025 & 0.9999 \\
$\begin{array}{c}\text { B2 High red blood cells } \\
\text { normal platelets }\end{array}$ & 0.999 & 5.123 & 0.9999 \\
\hline
\end{tabular}
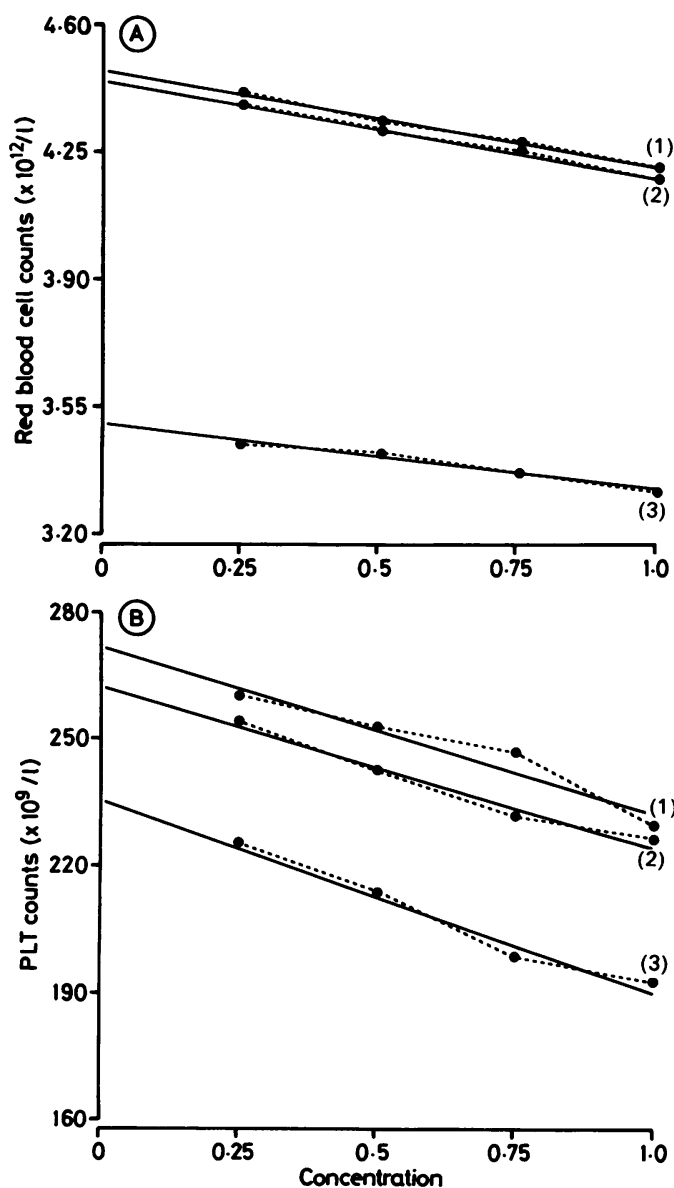

Figure 1 Coincidence correction

Relation of slope (coincidence counts) to intercept

(corrected counts) on linear scale:

(A) $R B C[y=446-26 X(r=-0.9977)$;

$y=443-24 X(r=-0.9996)$

$y=352-17 X(r=-0.9942)]$

(B) PLT $y=272-40 X(r=-0.9751)$;

$y=262-38 X(r=-0.9936)$;

$y=235-47 X(r=-0.9926)]$
In a second experiment (B) two different specimens were used, (1) low red blood cells and high platelets for assessing platelets and (2) high red blood cells and normal platelets for assessing red blood cells. These preparations were made artificially using platelet rich plasma, red cells, and bovine serum albumin in appropriate proportions. The ranges of concentrations were as follows:

\begin{tabular}{|lcll|}
\hline Experiment & $A$ & $B(1)$ & $B(2)$ \\
Red blood cells $\left(\times 10^{12} / 1\right)$ & $0-12$ & $0-4$ & $0-7$ \\
Platelets $\left(\times 10^{9} / 1\right)$ & $0-700$ & $0-800$ & $0-300$ \\
\hline
\end{tabular}

Results are shown in table 1 . The results indicate that there was no significant deviation from linearity for either red blood cells or platelets throughout the ranges tested.

\section{COINCIDENCE CORRECTION}

To check the validity of coincidence correction red blood cells and platelets were measured on a set of specimens at three further serial dilutions, to provide $3 / 4,1 / 2,1 / 4$ of the initial sample-that is, 1 in 666; 1 in 1000; and 1 in 2000 , respectively. Each sample was measured three times. Means were plotted on linear and logarithmic scales and extrapolated (figs $1 \mathrm{~A}$ and B). Analysis of variance (ANOVA) was carried out on the deviation of the mean from the regression line at each dilution. $F$ was calculated as the ratio of variance of mean from regression line to variance of replicate measurements. There was no evidence of nonlinearity; extrapolation to zero is identical with the theoretical prediction.

PRECISION

Two different experiments were performed: (A) 10 consecutive counts were made with continuous mixing on three samples of low, mid, and high red blood cell and platelet concentrations. The results were as follows:

\begin{tabular}{|llll|}
\hline & \multicolumn{4}{l|}{ Concentration } \\
\cline { 2 - 4 } Total instrument & Low & Mid & High \\
Red blood cells (mean) & 48671 & 93826 & 176996 \\
CV & $0.52 \%$ & $0.61 \%$ & $0.51 \%$ \\
Platelets (mean) & 3773 & 6703 & 11059 \\
CV & $1.81 \%$ & $1.34 \%$ & $0 \cdot 72 \%$ \\
\hline
\end{tabular}

(B) Within and between batch precision was measured using a two way analysis of variance as described by ICSH. ${ }^{5}$ Twenty samples (count range: $2 \cdot 55-5 \cdot 78 \times 10^{12} / 1$ for red blood cells; $64-678 \times 10^{9} / 1$ for platelets) were analysed in triplicate in three batches. The results were as follows:

\begin{tabular}{|lll|}
\hline & $\begin{array}{l}\text { Red } \\
\text { blood } \\
\text { cells }\end{array}$ & Platelets \\
Mean instrument count & & \\
number & 89774 & 4924 \\
Intrabatch CV & $0 \cdot 38 \%$ & $2 \cdot 05 \%$ \\
Interbatch CV & $0 \cdot 39 \%$ & $2 \cdot 11 \%$ \\
\hline
\end{tabular}


CARRY-OVER

In both laboratories carry-over was assessed using the Broughton method, ${ }^{7}$ as recommended by ICSH. ${ }^{5}$ The results were as follows:

\begin{tabular}{|lll|}
\hline & Red blood cells & Platelets \\
Laboratory A & $0.01 \%$ & $1.03 \%$ \\
Laboratory B & $0.42 \%$ & $0 \cdot 10 \%$ \\
\hline
\end{tabular}

DRIFT

A mixture of latex particles of $2.0 \mu \mathrm{m}$ (surrogate platelets) and $4.8 \mu \mathrm{m}$ (surrogate red cells) diameter (BCR Certified Reference Material No CRM 165 and CRM 166, respectively; Community Bureau of Reference of the Commission of the European Communities, Brussels) was used over an eight hour period to assess instrument stability. The material was measured five times in each hour. The overall reproducibility of the data from this experiment is a measure of drift or its absence.

Results are displayed graphically in fig 2 . This suggested a slight drift, especially with Certified Reference Materials 165, a one-way analysis of variance gave a CV of $1.34 \%$ for red cells and $1.27 \%$ for platelets with no measurement outside this range; thus no significant instrument drift had occurred.

Figure 2 Instrument stability, using monosised latex preparations: RM165 and RM166 refer to the certified reference materials (CRM) of the European Communities Bureau of Reference.

Figure 3 Specimen stability: $(A)$ platelet counts at room temperature; $(B)$ platele counts at $4^{\circ} \mathrm{C} ;$ (C) red blood cells at room temperature; (D) red blood cells at $4^{\circ} \mathrm{C}$.

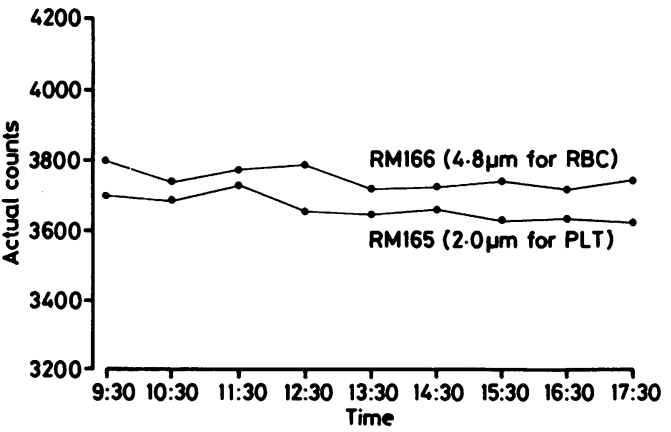

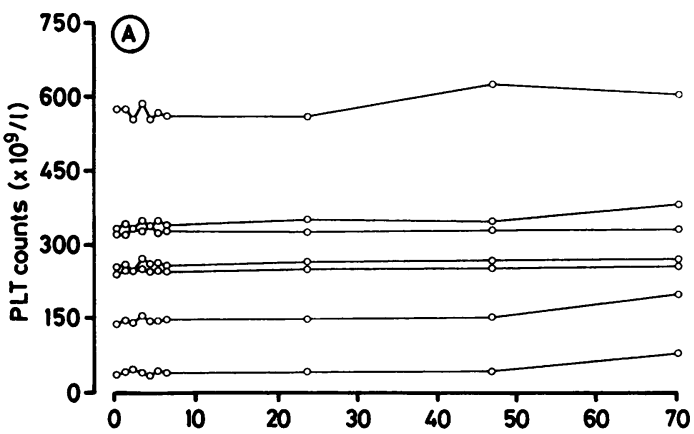
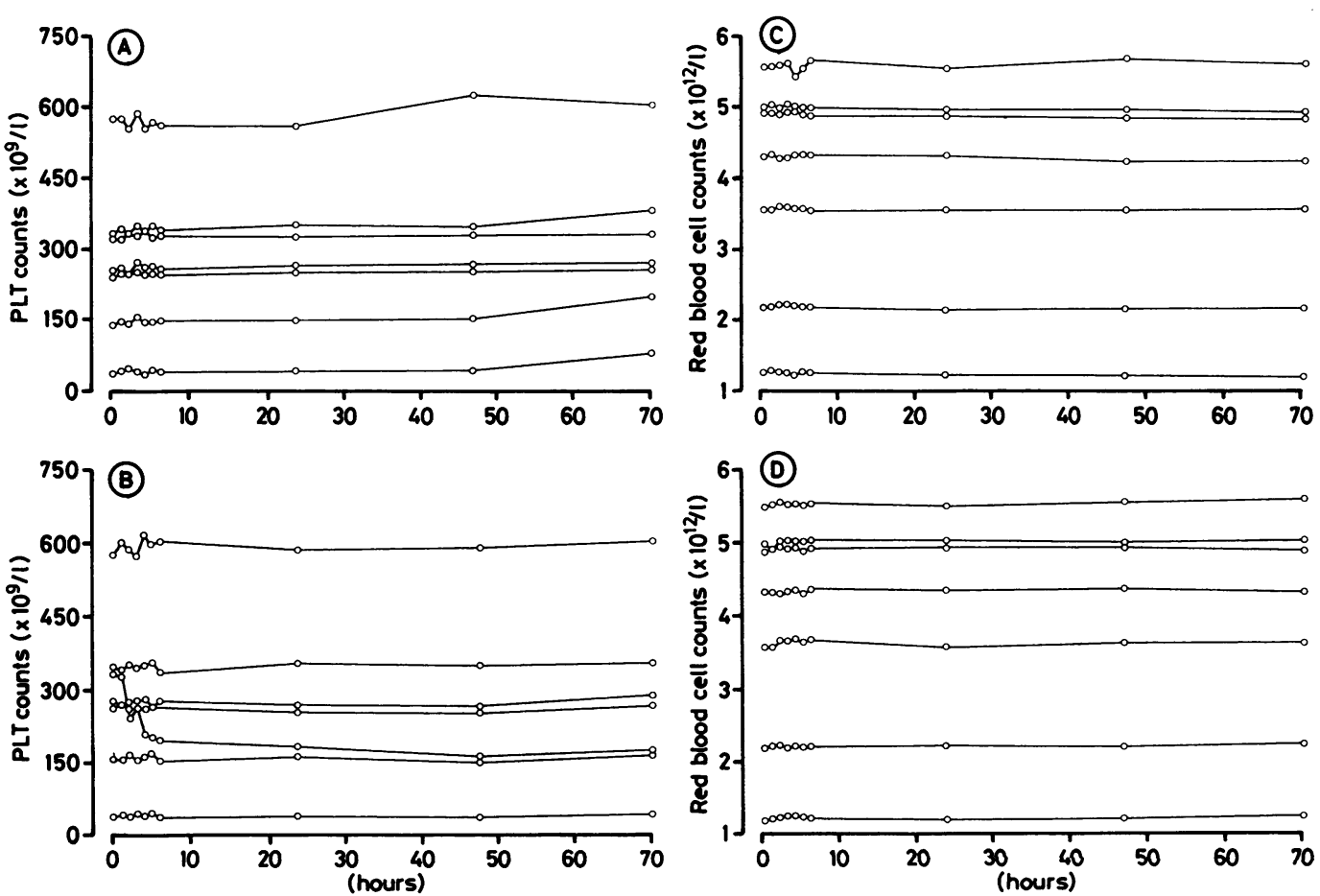

\begin{tabular}{|llllll|}
\hline \multicolumn{4}{c}{$\begin{array}{l}\text { Sample number } \\
\text { Sobservers } \\
\text { Low Mid High }\end{array}$} & $\begin{array}{l}\text { Nor visual } \\
\text { counting }\end{array}$ & $\begin{array}{l}\text { Reference } \\
\text { red cell } \\
\text { counter }\end{array}$ \\
Lab A & 10 & 20 & 10 & 1 & Toa $^{2}$ \\
Lab B & 13 & 10 & 14 & 3 & Coulter \\
& & & & ZF
\end{tabular}

Comparisons were assessed when results were stratified into those falling into the low, the middle, or the high parts of the range.

SPECIMEN STABILITY

An experiment was designed to assess the stability of red blood cells and platelets in specimens with increasing time after collection and any effect of time lapse on counts obtained. Seven specimens were selected from the routine workload including examples of low and high platelet count. Aliquots from each were stored at room temperature and at $4^{\circ} \mathrm{C}$ and measured hourly during the first six hours and subsequently at 24,48 , and 72 hours following venesection (fig 3 ). Results of platelet counts are displayed in table 2.

\section{COMPARABILITY}

Platelet counts obtained from the Model SSF were compared with those obtained by differential centrifugation ${ }^{89}$ by single channel aperture-impedance counters and with those obtained by a standardised visual microscopy method ${ }^{10}$ with phase contrast (in Laboratory A) or ordinary light microscopy (in Laboratory B). Red cell counts derived from the SSF were compared with those from a semiautomated single channel aperture-impedance instrument using thresholding specifications defined by ICSH (1988). ${ }^{1}$ Studies were performed in both laboratories using similar protocols with the following results: 
Table 2 Stability of platelet counts on storage

\begin{tabular}{|c|c|c|c|c|c|c|c|c|c|c|c|c|c|c|}
\hline \multirow[b]{2}{*}{ Hours } & \multicolumn{7}{|c|}{ Room temperature } & \multicolumn{7}{|l|}{$4^{\circ} \mathrm{C}$} \\
\hline & 1 & 2 & 3 & 4 & 5 & 6 & 7 & 1 & 2 & 3 & 4 & 5 & 6 & 7 \\
\hline $\begin{array}{l}0 \\
1 \\
2 \\
3 \\
4 \\
5 \\
6 \\
24 \\
48 \\
72 \\
\text { CV\% }\end{array}$ & $\begin{array}{l}247 \\
255 \\
251 \\
260 \\
253 \\
255 \\
260 \\
257 \\
262 \\
264 \\
2.02\end{array}$ & $\begin{array}{l}262 \\
266 \\
257 \\
279 \\
266 \\
268 \\
261 \\
272 \\
273 \\
277 \\
2.65\end{array}$ & $\begin{array}{c}330 \\
328 \\
340 \\
337 \\
349 \\
332 \\
333 \\
333 \\
337 \\
338 \\
1 \cdot 79\end{array}$ & $\begin{array}{c}339 \\
348 \\
342 \\
355 \\
346 \\
355 \\
346 \\
358 \\
356 \\
389 \\
3.96\end{array}$ & $\begin{array}{l}145 \\
151 \\
146 \\
160 \\
150 \\
151 \\
153 \\
152 \\
155 \\
204 \\
10.9\end{array}$ & $\begin{array}{l}583 \\
583 \\
561 \\
593 \\
561 \\
577 \\
569 \\
568 \\
634 \\
614 \\
4 \cdot 06\end{array}$ & $\begin{array}{l}35 \\
40 \\
47 \\
42 \\
35 \\
44 \\
40 \\
43 \\
42 \\
78^{\star} \\
27 \cdot 4\end{array}$ & $\begin{array}{c}251 \\
260 \\
249 \\
250 \\
246 \\
252 \\
255 \\
249 \\
245 \\
260 \\
2.06\end{array}$ & $\begin{array}{c}266 \\
256 \\
264 \\
268 \\
272 \\
256 \\
268 \\
255 \\
254 \\
280 \\
3 \cdot 20\end{array}$ & $\begin{array}{c}327 \\
320 \\
232 \\
255 \\
202 \\
195 \\
191 \\
179 \\
158 \\
172 \\
26 \cdot 8\end{array}$ & $\begin{array}{c}339 \\
333 \\
344 \\
338 \\
342 \\
347 \\
328 \\
347 \\
344 \\
348 \\
1.9\end{array}$ & $\begin{array}{l}150 \\
150 \\
160 \\
150 \\
155 \\
160 \\
148 \\
158 \\
149 \\
160 \\
3.3\end{array}$ & $\begin{array}{l}577 \\
601 \\
589 \\
573 \\
615 \\
599 \\
601 \\
587 \\
590 \\
609 \\
2 \cdot 2\end{array}$ & $\begin{array}{l}36 \\
42 \\
35 \\
41 \\
33 \\
45 \\
35 \\
38 \\
35 \\
43 \\
23 \cdot 4\end{array}$ \\
\hline
\end{tabular}

Each vertical column indicates count obtained at $0,1,2,3,4,5,6,24,48$ and 72 hour after venesection. Specimen 3 at $4^{\circ} \mathrm{C}$ shows fall in count by two hours; this was due to agglutination not adequately dispersed by mixing.

^Excluding this aberrant result, CV was $9 \cdot 66 \%$.

\begin{tabular}{|llllll|}
\hline & & \multicolumn{4}{c|}{$\begin{array}{c}\text { Mean platelet counts } \\
\left(\times 10^{9} / l\right)\end{array}$} \\
\cline { 3 - 5 } & & & \\
& & Low Mid High & Overall \\
Lab A & Centrifuge & 99 & 280 & 555 & 304 \\
$(\mathrm{n}=40)$ & Visual & 88 & 291 & 576 & 312 \\
& SSF & 93 & 293 & 586 & 316 \\
Lab B & Centrifuge & 100 & 275 & 524 & 308 \\
$(\mathrm{n}=37)$ & Visual & 93 & 263 & 544 & 310 \\
& SSF & 85 & 268 & 519 & 299 \\
& & & & \\
\hline
\end{tabular}

Correlation graphs of platelets counts by SSF and the visual reference method are shown in fig 4. Correlation of visual and centrifugation methods are shown in fig 5 .

Regression analysis has been done separately
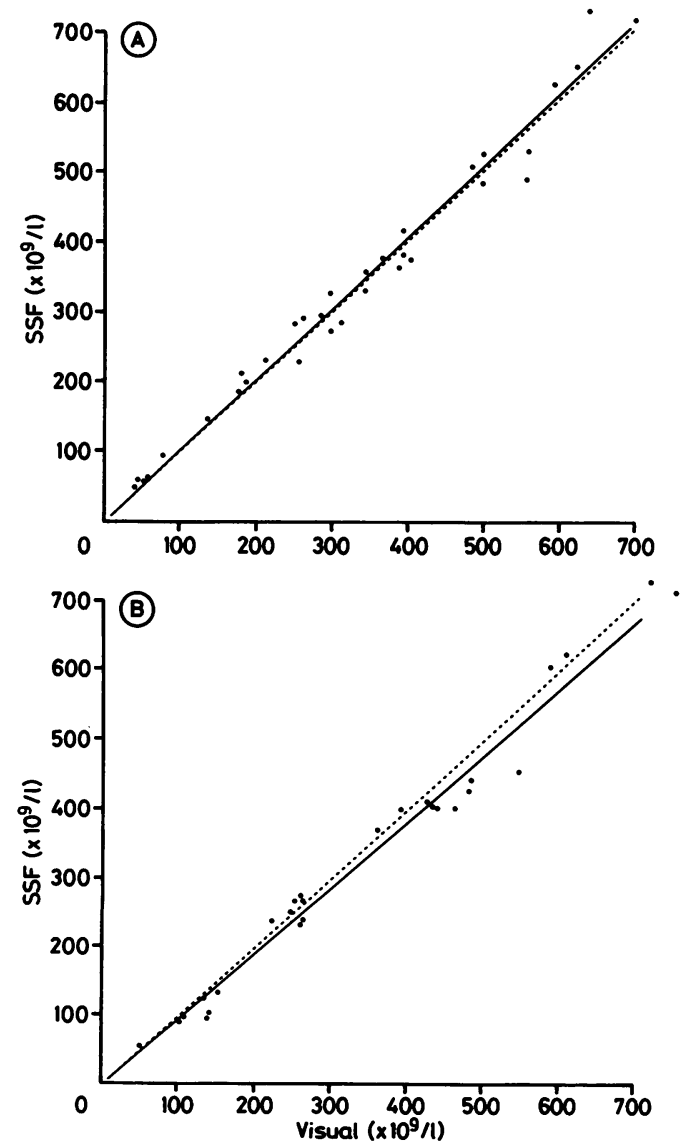

Figure 4 Comparison of platelet counts by SSF and visual reference method in Lab $A:(A)$ [ $r=0.9920$; intercept $=2 \cdot 1378$; slope $=+1.0078]$ and Lab B:

(B) $[r=0.9936 ;$ intercept $=3.2512 ;$ slope $=$ $+0.9537]$. with the visual and centrifugation methods with the following results:

(a) With visual counting method:

Corre-

lation Slope $Y$-inter df t test

$\begin{array}{lllll}\text { Lab A } .9920 & 1.01 & 2 \cdot 14 & 39 & -1.199\end{array}$

(NS)

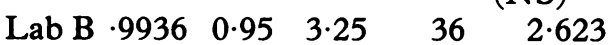

$(\mathrm{p}=0.05)$

(b) with centrifugation method:

Lab A $.9973 \quad 1.8 \quad-11.2139 \quad-4.042$

$\begin{array}{lllll}\text { Lab B } & .9933 & 1.02 & -15.9736 & 2.233\end{array}$ $(\mathrm{p}=0.05)$

$(36 \mathrm{df})=2.028$ at $\mathrm{p}=0.05,2.719$ at $\mathrm{p}=0.01$

$t(39 \mathrm{df})=2.023$ at $\mathrm{p}=0.05,2 \cdot 708$ at $\mathrm{p}=0.01$
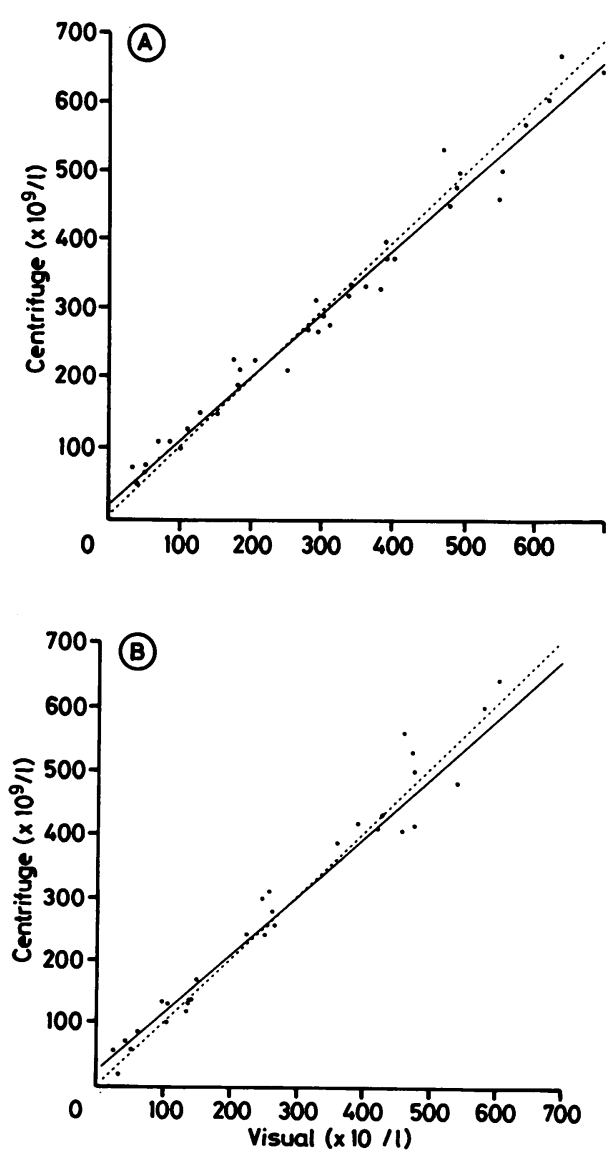

Figure 5 Comparison of platelet counts by visual and centrifugation reference methods in Lab $A:(A)[r=$ 0.9909; intercept $=13.4844$; slope $=+0.9311]$ and Lab B: $(B)[r=0.9868 ;$ intercept $=22.6858 ;$ slope $=$ $+0.9201]$ 
Correlation of visual and centrifugation methods were as follows:

\begin{tabular}{|cllll|}
\hline $\begin{array}{c}\text { Corre- } \\
\text { lation }\end{array}$ & Slope & $Y$-inter & $d f$ & $t$-test \\
Lab A .9099 & 0.93 & 13.48 & 39 & 1.870 \\
Lab B .9868 & 0.92 & 22.68 & 36 & 0.337 \\
\hline
\end{tabular}

\section{Discussion}

Automated platelet counting is now generally performed on whole blood, the platelets being identified by a size discrimination procedure. It is therefore desirable to have a reference method which is also capable of counting platelets on whole blood specimens to assign values to reference preparations for use in calibration.

The instrument described in this study is intended for this purpose. The common causes of inaccuracy are dilution error, coincidence counts, counting loss of small platelets and inadequate discrimination. To minimise systematic errors there is a sheath flow, $50 \mu \mathrm{m}$ (diameter) $\times 60 \mu \mathrm{m}$ (length) orifice, extrapolation correction, and, to avoid dilution errors, red blood cells and platelets are counted proportionately in a fixed volume.

The instrument was evaluated in accordance with the ICSH protocol for the evaluation of automated blood cell counters. ${ }^{5}$

The results indicate that this instrument is capable of a high level of linearity and precision, accurate coincidence correction, controlled volume, stability and negligible carry-over. Comparison with established methods was satisfactory, but minor differences are likely to be a reflection of variability by the traditional techniques rather than due to any inaccuracy by the SSF. Thus the SSF seems to be eminently suitable as a candidate reference instrument for platelet counting.

$1 \mathrm{ICSH}$. The assignment of values to fresh blood used for calibrating automated blood cell counters. Clin Lab Haematol 1988;10:203-12.

2 Lewis SM, England JM, Rowan RM, Kubota F. Standardisation for haemocytometry. Lab Practice 1989;38:68-9.

3 Lewis SM, England JM, Kubota F. Coincidence correction in red blood cell counting. Phys Med Biol 1989;34: 1239-46.

4 Groner W, Epstein E. Counting and sizing of blood cells using light scattering. In: van Assendelft $O W$, England JM, eds. Advances in haematological methods: The blood count. Boca Raton, Florida: CRC Press, 1982:74-84.

$5 \mathrm{ICSH}$. Protocol for evaluation of automated blood cell counters. Clin Lab Haematol 1984;6:69-84.

$6 \mathrm{ICSH}$. Recommendations for reference method for haemoglobinometry in human blood and specifications for international haemoglobincyanide reference preparation (3rd edition). Clin Lab Haematol 1987;9:73-9.

7 Broughton PMG, Gowenlock AN, McCormack JJ, Nei DW. A revised scheme for the evaluation of automated instruments for use in clinical chemistry. Ann Clin Biochem 1974;11:207-18.

8 Cousins S, Lewis SM. A rapid and accurate differential centrifugation method for platelet counts. J Clin Pathol 1982;35:114-16.

9 Lewis SM, Skelly JV, Cousins S. Automated platelet counting - a re-evaluation of the sedimentation methods. Clin Lab Haematol 1981;3.215-22.

10 Lewis SM, Wardle J, Cousins S, Skelly JV. Platelet counting-development as a reference method and a reference preparation. Clin Lab Haematol 1979;1:227-37. 